\title{
ANALISIS KEMOMETRIK SENYAWA INHIBITOR TIROSINASE MENGGUNAKAN SPEKTROFOTOMETER IR (FTIR)
}

\author{
Yus Risal dan Yusnita Rifai \\ Laboratorium Kimia Farmasi, Fakultas Farmasi, Universitas Hasanuddin, Makassar, Indonesia
}

\begin{abstract}
Kata Kunci
Inhibitor tirosinase, arbutin, asam kojik, Curcuma xanthorrhiza, Curcuma zedoaria, Lavandula afficianalis, Ocimum basilicum, Piper cubeba, Piper retrofractum dan Zingiber zerumbet, Kemometrik
\end{abstract}

\begin{abstract}
ABSTRAK
Analisis kesamaan dan karakteristik yang khas dari beberapa senyawa inhibitor tirosinase telah dilakukan. Senyawa inhibitor tirosinase tersebut seperti arbutin, asam kojik (sebagai pengontrol) dari beberapa ekstrak seperti ekstrak temu lawak (Curcuma xanthorrhiza), ekstrak kunyit putih (Curcuma zedoaria), ekstrak lavender (Lavandula afficianalis), ekstrak selasih (Ocimum basilicum), ekstrak kemukus (Piper cubeba), ekstrak cabai jawa (Piper retrofractum) dan ekstrak lempuyang (Zingiber zerumbet) menggunakan alat spektrofotometer infra merah (FTIR) dan selanjutnya dilanjutkan diolah data dengan metode kemometrik yang terdiri dari PCA (Principal Component Analysis) dan CA (Cluster Analysis). Dari hasil penelitian, data PCA yang dicapai komponen utama dengan eigenvalue sekitar 99,8 $\%$ dari total varian, sedangkan PCA didapatkan senyawa inhibitor tirosinase berupa senyawa asam kojik, ekstrak lempuyang, ekstrak selasih dan ekstrak lavender berada dalam satu kuadran. Asam kojik menunjukkan adanya kemiripan dengan ekstrak lempuyang dengan tingkat kesamaan adalah 75,85 dan jarak Euclidean 0,202, pada analisis CA.
\end{abstract}

\section{PENDAHULUAN}

Senyawa inhibitor tirosinase biasanya digunakan sebagai bahan pencerah atau pemutih kulit. Senyawa anti tirosinase diperoleh dari 2 cara yakni alami dan sintesis, jenis- jenis anti tirosinase seperti arbutin, hidrokinon, asam askorbat, retinoid serta asam kojik. Arbutin dan asam kojik termasuk salah satu inhibitor tirosinase, akhirakhir ini menjadi subjek penelitian[3, 11, 12], juga digunakan sebagai anti inflamasi[7], pencegahan radikal bebas[5], dengan aktifitas antibakteri yang kuat[13]. Asam kojik sebagai penghambat tirosinase, enzim yang mengubah tirosin menjadi melanin[10,12], pada pasien melasma asam kojik mampu menghambat pigmen, asam kojik biasanya terdapat dalam jamur Aspergilline oryzae ${ }^{[4]}$. Asam kojik banyak digunakan pada kosmetik sebagai pemutih yang efektif[11]. Asam kojik berasal dari jamur $A$. flavus, $A$. oryzay, $A$. tamarii serta $A$. parasiticus. Sedangkan untuk arbutin berasal dari tanaman berspesies Ericaceae spesies Arctostaphylos uva-ursi mempunyai kandungan arbutin yang cukup tinggi, arbutin merupakan bahan aktif sebagai agen pencerah kulit untuk mencegah pembetukan melanin ${ }^{[3]}$.

Dari ke-2 senyawa inhibitor tirosinase tersebut saat ini banyak digunakan sebagai produk-produk kosmetik serta farmasi yakni arbutin dan asam kojik, serta ada beberapa ekstrak yang diuji untuk mencari kemiripan yang khas tentang kedekatan senyawa inhibitor tirosinase yaitu ekstrak temu lawak (Curcuma xanthorrhiza), ekstrak kunyit putih (Curcuma zedoaria), ekstrak lavender (Lavandula afficianalis), ekstrak selasih (Ocimum basilicum), ekstrak kemukus (Piper cubeba), ekstrak cabai jawa (Piper retrofractum) dan ekstrak lempuyang (Zingiber zerumbet), dengan menggunakan spektrofotometer infra merah (FTIR), serta untuk pengelolaan data menggunakan aplikasi minitab. Penelitian bertujuan untuk mendapatkan derivat atau turunan baru dari senyawa inhibitor tirosinase dari beberapa ekstrak yang diujikan dan sebagai

Spektrofotometer Fourier Transform Infrared (FTIR) digunakan karena analisis kimia pada perolehan spektra yang cepat dengan jumlah yang banyak[7,8], analisis ini paling banyak dipakai untuk analisis kualitatif[1]. FTIR biasanya digunakan untuk mengidentifikasi suatu senyawa dimana parameternya adalah bilangan gelombang yang timbul akibat adanya serapan oleh gugus fungsi yang khas pada senyawa tersebut. Pengolahan data spektra infra merah dilakukan dengan memakai metode statistik multvariat (kemometrik).

Teknik yang paling banyak digunakan di akhirakhir ini dalam menganalisa kesamaan karakteristik beberapa komponen kimia adalah kemometrik, diantaranya ialah penentuan multivarian untuk menguraikan hubungan antara sampel dengan beberapa variabel[10]. Kemometrik adalah aplikasi (software) dari minitab dimana aplikasi tersebut mengkombinasikan antara ilmu kimia dengan ilmu statistik ${ }^{[2,6,9,10]}$. Dari hasil uraian, penulis ingin menganalisis dan menguraikan hasil spektra FTIR dan mengelola data tersebut diaplikasi dalam metode penentuan Principal Component Analysis (PCA) serta clusternya CA atau pengelompokkan dari senyawa inhibitor tirosinase.

\section{METODE PENELITIAN}

\section{Bahan}

Arbutin, asam kojik, ekstrak temu lawak (Curcuma xanthorrhiza), ekstrak kunyit putih (Curcuma zedoaria), ekstrak lavender (Lavandula afficianalis), ekstrak selasih (Ocimum basilicum), ekstrak kemukus (Piper cubeba), ekstrak cabai jawa (Piper retrofractum) dan ekstrak lempuyang (Zingiber zerumbet). pembanding yaitu adalah arbutin dan asam kojik. 


\section{Pengukuran Analisis Spektrum FTIR}

Pengukuran spektra dari semua sampel dilakukan dengan menggunakan spektrofotometer FTIR (Shimadzu). Spektrum dipindai di wilayah infra merah (400-4000 $\left.\mathrm{cm}^{-1}\right)$ karena banyak informasi yang dicakup di wilayah ini. Di wilayah sidik jari semua profil sampel berbeda-beda, tergantung pada getaran molekul yang khas pada sampel. Spektro FTIR ini memiliki kemampuan yang cepat dalam menganalisa, bersifat tidak merusak serta dibutuhkan preparasi sampel yang sederhana. spektrometer FTIR yang dilengkapi dengan deuterasi trigliserin sulfat (DTGS) detektor KBr sebagai pembagi berkas. Instrumen ini terhubung ke perangkat lunak sistem operasi omnic dihubungkan ke komputer yang berbasis windows.

\section{Analisis Kemometrik}

Analisis komponen utama atau principal component analysis (PCA) menggunakan absorbansi dari spektra FTIR serta cluster analysis (CA) digunakan perangkat lunak dengan Minitab 18.

\section{HASIL DAN PEMBAHASAN}

Dari hasil spektra masing-masing sampel didapatkan peak masing-masning sampel dari bilangan gelombang (lihat gambar 4-12).

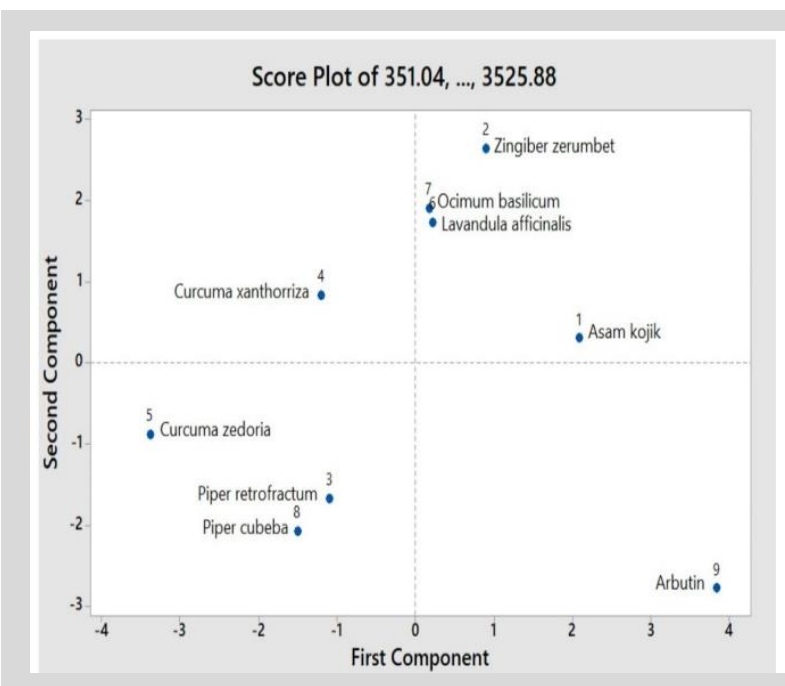

Gambar 1. Score Plot pada sampel

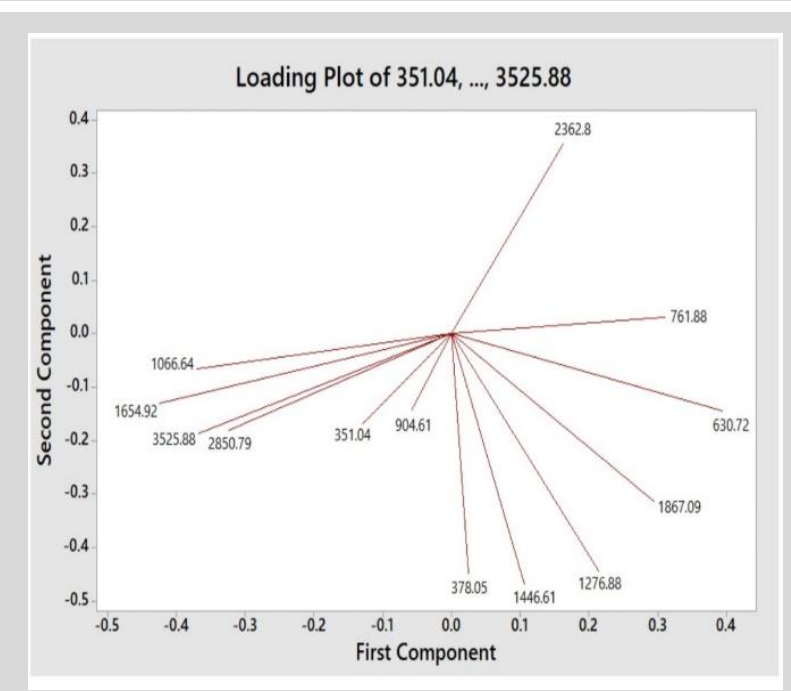

Gambar 2. Loading Plot Principal Component Analysis (PCA)

Untuk mengetahui senyawa inhibitor tirosinase baik itu senyawa asam kojik serta arbutin dan dengan beberapa ekstrak yang telah disediakan untuk diteliti untuk mencari kemiripan atau kedekatan yang khas dekat dengan senyawa inhibitor tirosinase, yang mana lebih dekat antara arbutin atau asam kojik.

Didalam penelitian, ada 9 macam sampel dua yaitu 2 senyawa inhibitor tirosinase serta 7 ekstrak yang telah disiapkan sebelumnya, untuk melihat kedekatan/ kemiripan yang hampir sama atau kedekatan yang khas dari antara dua senyawa arbutin atau asam kojik diantara beberapa sampel ekstrak tersebut (lihat Gambar 1).

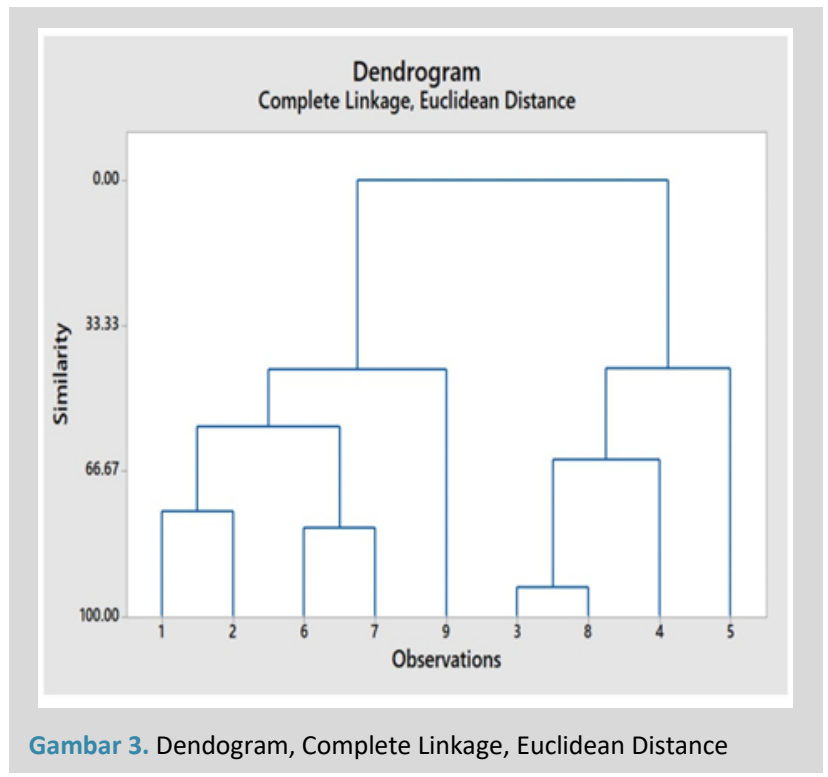

Pada Gambar 1 tersebut, kita membuat beberapa kuadran untuk pengelompokkannya, untuk kuadran 1 hingga 4 atau kelompok 1 hingga 4, dalam kelompok I yaitu ekstrak Curcuma xanthorriza, kelompok 2 yaitu terdiri atas asam kojik, ekstrak Zingiber zerumbet, ekstrak Lavandula afficianalis serta ekstrak Ocimum basilicum; kelompok 3 terdiri dari ekstrak Curcuma zedoria, ekstrak Piper retrofractum dan ekstrak Piper cubeba; kelompok 4 yaitu arbutin.

Pada Gambar 2 tersebut, menunjukkan loading plot (PCA) hasil dari 9 sampel dimana nilai Principal Component First (PC1) memberi sumbangan terbesar sedangkan untuk Principal Component Second (PC2) menyumbang variasi besar berikut setelah PC1 dan seterusnya. Pada PC1 memberikan varian sebesar 4,5339 atau 34,9\%, pada PC2 memberikan varian sebesar 3,7508 atau 28,9\%, jadi PC1 dan PC2 memberikan total varian (proportion cumulative) sebesar $63,8 \%$ dari total seluruh varian, nilai ini memberikan proporsi terbesar dibandingkan dengan PC lainnya. Selain itu, loading plot menggambarkan proyeksi variabel dalam bidang yang sama dengan score plot. Menurut Abdul Rohman di dalam bukunya tentang statistika dan kemometrik tahun 2014, semakin jauh titik variabel dari titik asal variabel, maka semakin besar kontribusi variabel tersebut (PCA).

Pada Gambar 3, menunjukkan tahapan hubungan antar beberapa sampel yang diujikan, pada step 1 sampel 3 (ekstrak Piper retrofractum) dan sampel 8 (ekstrak Piper cubeba) membentuk kluster baru (new cluster) 3 dengan tingkat kesamaan (similarity level) 93,2860 serta tingkat jarak (distance level) 0,05631; pada step 2, sampel 6 (ekstrak Lavandula afficianlis) dengan sampel 7 (ekstrak Ocimum basilicum) membentuk kluster baru 6 dengan tingkat kesamaan 79,7461 serta tingkat jarak 0,169873; step 3 sampel 1 (asam kojik) dengan sampel 2 (ekstrak Zingiber zerumbet) membentuk kluster baru 1 dengan tingkat kesamaan 75,8547 serta tingkat jarak 0,202512; step 4 sampel 3 (ekstrak Piper retrofractum) dengan sampel 4 
(ekstrak Curcuma xanthorriza) membentuk kluster baru 3 dengan tingkat kesamaan 63,9874 serta tingkat jarak 0,302045; step 5 sampel 1 (asam kojik) dengan sampel 6 (ekstrak Lavandula afficianalis) membentuk kluster baru 1 dengan tingkat kesamaan 56,4781 serta tingkat jarak 0,365027; step 6 sampel 1 (asam kojik) dengan sampel 9 (arbutin) membentuk kluster baru 1 dengan tingkat kesamaan 43,3708 serta tingkat jarak 0,474961; step 7 sampel 3 (ekstrak Piper retrofractum) dengan sampel 5 (ekstrak Curcuma zedoria) membentuk kluster baru 3 dengan tingkat kesamaan 2,9483 serta tingkat jarak 0,478505; step 8 sampel 1 (asam kojik) dengan sampel 3 (ekstrak Piper retrofractum) membentuk kluster baru 1 dengan tingkat kesamaan 0,0000 serta tingkat jarak 0,838722. Dilihat dari model dendrogram yang terbentuk sehingga dapat diketahui bahwa besar nilai kesamaan (similarity) dari garis yang menghubungkan antara sampel satu dengan sampel yang lainnya. Menurut Che Man serta kawan-kawannya ditahun 2010[1], dimana keuntungan CA atas PCA adalah CA memberikan kesamaan nilai- nilai numerik diantara objek yang dievaluasi atau diujikan, dimana informasi yang diperoleh lebih objektif serta lebih selektif yaitu seperti pada hasil penelitian dimana asam kojik, ekstrak lempuyang (Zingiber serumbet), ekstrak selasih (Ocimum basilicum) serta ekstrak lavender (Lavandula afficianalis) berada dalam satu kelompok.

\begin{tabular}{|c|c|c|c|c|c|c|c|c|c|c|}
\hline \multicolumn{9}{|c|}{ Bilangan gelombang $\left(\mathrm{cm}^{-1}\right)$} & \multirow{2}{*}{$\begin{array}{c}\text { Fungsional } \\
\text { group }\end{array}$} & \multirow[b]{2}{*}{ Intensitas } \\
\hline $\begin{array}{l}\text { Asam } \\
\text { kojik }\end{array}$ & $\begin{array}{l}\text { Zingiber } \\
\text { zerumbet }\end{array}$ & $\begin{array}{c}\text { Piper } \\
\text { retrofactum }\end{array}$ & $\begin{array}{c}\text { Curcuma } \\
\text { Xanthoriza }\end{array}$ & $\begin{array}{l}\text { Curcuma } \\
\text { zedoria }\end{array}$ & $\begin{array}{l}\text { Lavandula } \\
\text { afficinialis }\end{array}$ & $\begin{array}{l}\text { Ocimum } \\
\text { basilicum }\end{array}$ & Piper cubeba & Arbutin & & \\
\hline $\begin{array}{l}3525, \\
3340, \\
3234\end{array}$ & 3504 & 3419 & 3402 & 3412 & 3412 & 3412 & 3417 & 3317 & $\begin{array}{c}\mathrm{OH} \\
\text { stretching }\end{array}$ & Strong \\
\hline $\begin{array}{l}1654 \\
1593 \\
1560 \\
1500\end{array}$ & $\begin{array}{l}1651, \\
1514\end{array}$ & $\begin{array}{l}1635 \\
1591 \\
1512\end{array}$ & $\begin{array}{c}1645 \\
1514\end{array}$ & $\begin{array}{l}1645 \\
1521\end{array}$ & $\begin{array}{l}1643 \\
1612 \\
1514\end{array}$ & 1645 & $\begin{array}{l}1635 \\
1591 \\
1548\end{array}$ & $\begin{array}{l}1699, \\
1629, \\
1516\end{array}$ & $\mathrm{C}=\mathrm{H}$ amide & Strong \\
\hline $\begin{array}{l}1473, \\
1446 \\
\end{array}$ & 1456 & 1446 & 1456 & 1456 & 1450 & 1452 & 1446 & 1475 & $\mathrm{CH}_{2}$ bend & Medium \\
\hline $\begin{array}{c}1165 \\
1136, \\
1093, \\
1066\end{array}$ & $\begin{array}{l}1242 \\
1161\end{array}$ & $\begin{array}{l}1197 \\
1157 \\
1078\end{array}$ & $\begin{array}{c}1240 \\
1207 \\
1159, \\
1078\end{array}$ & $\begin{array}{l}1244, \\
1155, \\
1080\end{array}$ & $\begin{array}{c}1205 \\
1155 \\
1099 \\
1057\end{array}$ & $\begin{array}{l}1153 \\
1099 \\
1033\end{array}$ & $\begin{array}{c}1197 \\
1157 \\
1078, \\
1024\end{array}$ & $\begin{array}{l}1240 \\
1093\end{array}$ & $\begin{array}{c}\mathrm{CO} \\
\text { stretching }\end{array}$ & strong \\
\hline
\end{tabular}

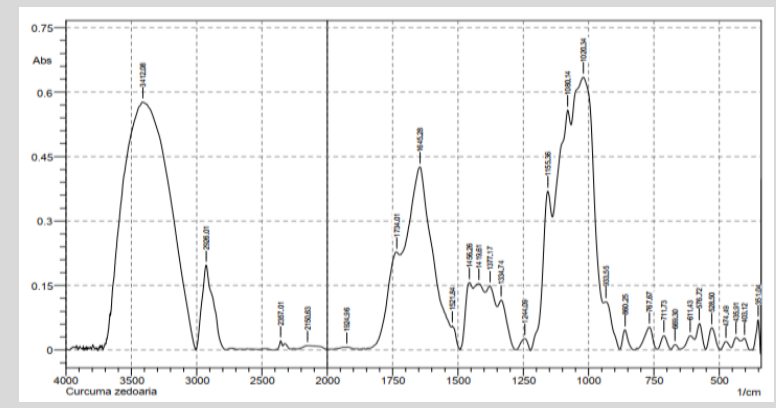

Gambar 4. FTIR ekstrak Curcuma zedoria (ekstrak kunyit putih)

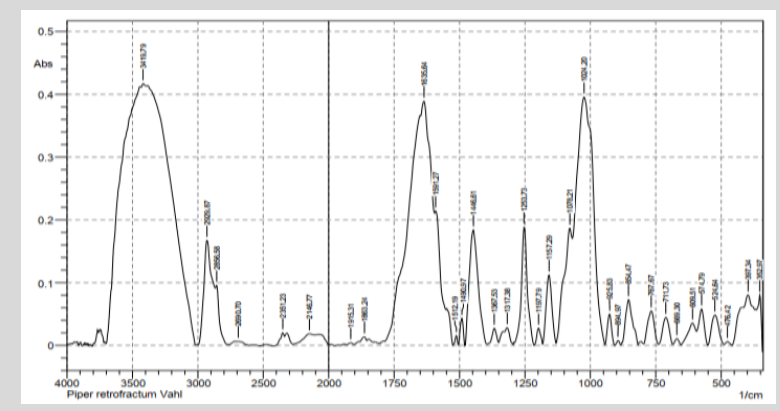

Gambar 5. FTIR ekstrak Piper retrofractum (ekstrak cabai jawa)

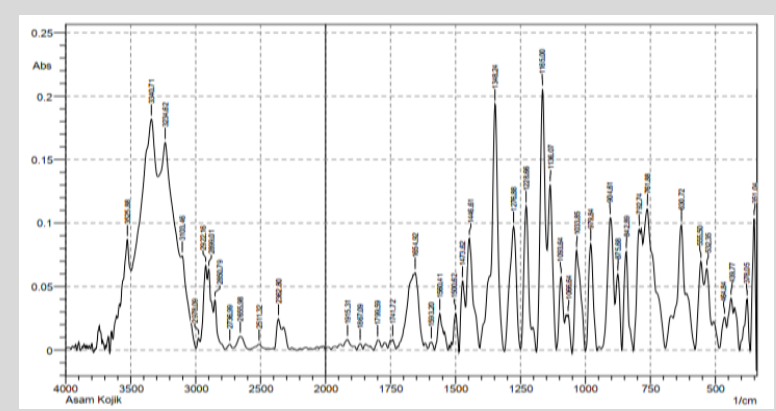

Gambar 6. FTIR asam kojik

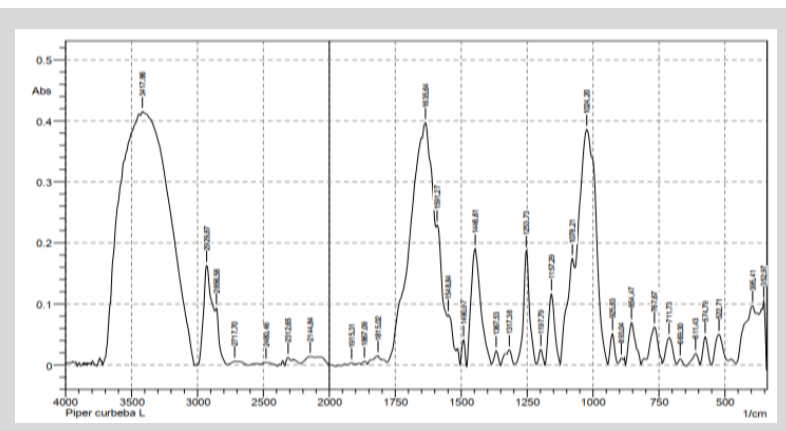

Gambar 7. FTIR ekstrak Piper cubeba (ekstrak kemukus)

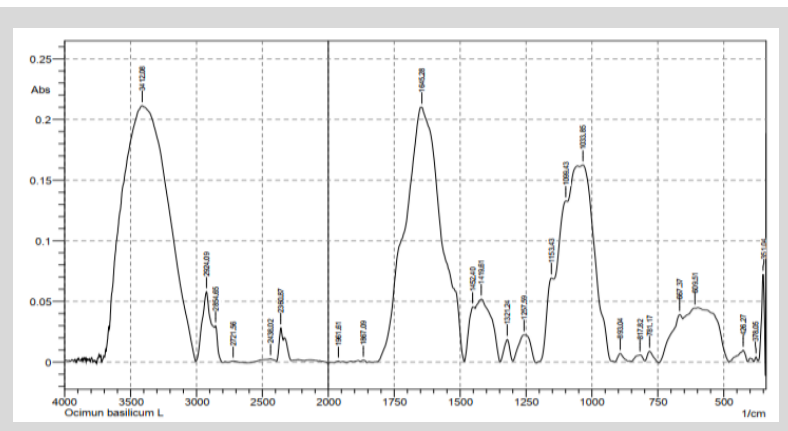

Gambar 8. FTIR ekstrak Ocimum basilicum (ekstrak selasih)

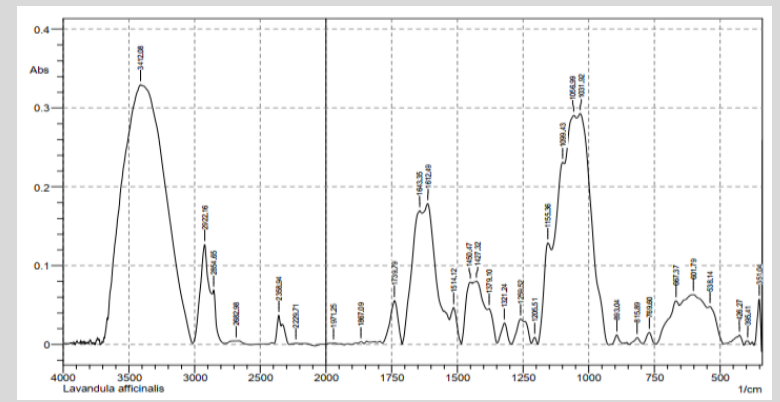

Gambar 9. FTIR ekstrak Lavandula afficianalis (ekstrak lavender) 


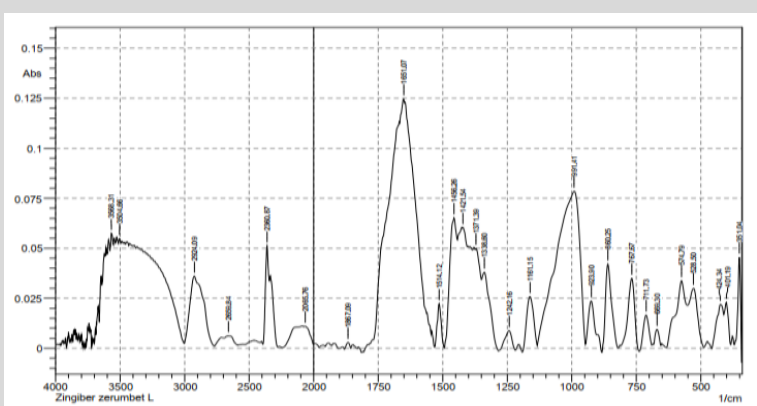

Gambar 10. FTIR ekstrak Zingiber zerumbet (ekstrak lempuyang)

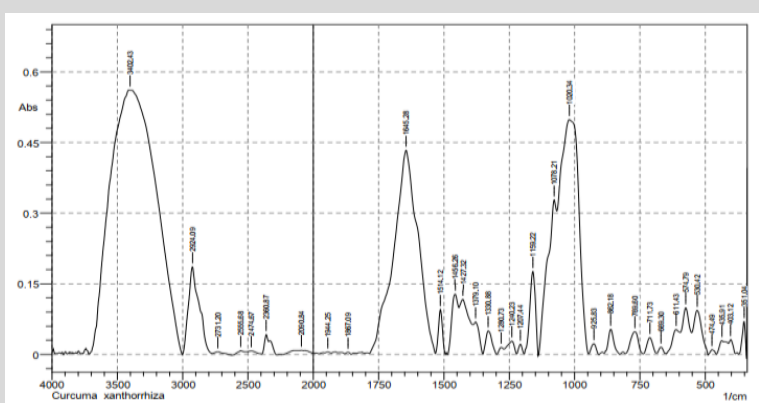

Gambar 11. FTIR ekstrak Curcuma xanthorriza (ekstrak temu lawak)

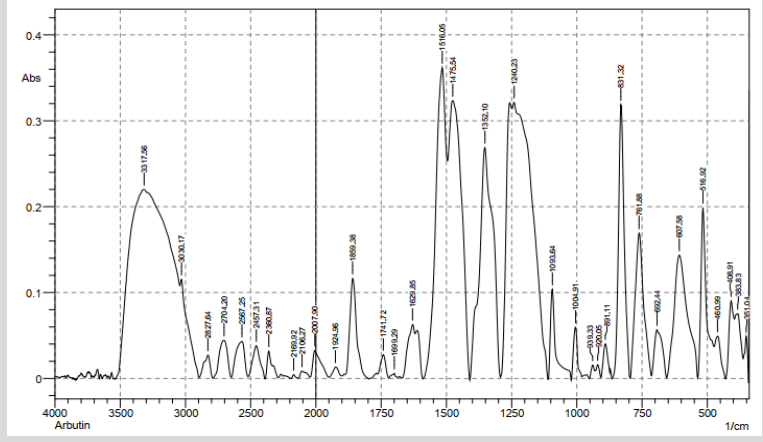

Gambar 8. FTIR arbutin

\section{KESIMPULAN}

Berdasarkan data dari analisis kemometrik, terdiri dari score plot terbagi dari 4 kelompok, dimana senyawa inhibitor tirosinase yaitu asam kojik dan arbutin berbeda kelompok, asam kojik berada satu kelompok dengan 3 ekstrak yaitu ekstrak lempuyang (Zingiber serumbet), ekstrak selasih (Ocimum basilicum), serta ekstrak lavender (Lavandula afficianalis). Sedangkan untuk senyawa arbutin tidak memiliki kelompok dari ekstrak yang diujikan

\section{UCAPAN TERIMA KASIH}

Peneltian ini didukung oleh Kementerian Riset, Teknologi dan Pendidikan Tinggi Republik Indonesia. Kami berterima kasih kepada Fakultas Farmasi dari Universitas Hasanuddin.

\section{DAFTAR PUSTAKA}

1. Che Man, Y. B., Rohman, A., \& Mansor, T. S. T. Differentiation of Lard from Other Edible Fats and Oils by Means of Fourier Transform Infrared Spectroscopy and Chemometrics. Journal of the American Oil Chemists' Society. 2010; 88(2), 187-192. DOI: 10.1007/s11746-010-1659-x

2. Bansal, A., Chhabra, V., Rawal, R. K, Sharma, S. Chemometrics: A new scenario in herbal drug standardization. Journal of Pharmaceutical Analysis. 2013. https://doi.org/10.1016/j.jpha.2013.12.001

3. Emea. Assessment report on Arctostaphylos uva-ursi (L) Spreng., folium European Medicines Agency. 2012.

4. Garcia A., Fulton J. E. The combination of glycolic acid and hydroquinone or kojic acid for the treatment of melasma and related conditions. Dermatol Surg. 1996; 22: 443-7. doi: 10.1111/j.15244725.1996.tb00345.x

5. Khadir, F., Pouramir, M; Joorsaraee, S, G; Feizi, F; Sorkhi, H; Yousefi, F. The Effect of Arbutin on Lipid Peroxidation and Antioxidant Capacity in The Serum of Cyclosporine-Treated Rats. Caspian Journal of Internal Medicine. 2015; 6 (4): 196-200. Sumber dari https://www.ncbi.nlm.nih.gov/pmc/articles/PMC4649267/

6. Lavine, B., Workman, J. 2010. Chemometrics. Anal.Chem. 2010; 82 4699-4711. https://doi.org/10.1021/ac101202z

7. Lee, H.J., Kim, K.W. Anti-Inflammatory Effects of Arbutin In Lipopolysaccharide-Stimulated BV2 Microglial Cell. SpringerInflammation Res. 2012; 61: 817-825

8. N. Benoudjit, E. Cools, M. Meurens, M. Verleysen Chemometric calibration of infrared spectrometers: selection and validation of variables by non-linear models, Chem. Intel Lab. System. 2004; 70, 47-53 R.G. Brereton. Introduction to multivariate calibration in analytical chemistry, analyst. 2000; 125, 2125-2154. DOI: 10.1039/b003805i

10. Rohman, A. Statistika dan Kemometrika Dasar dalam Analisis Farmasi Pustaka Pelajar. 2014

11. Saeedi Majid, Eslamifar Masoumeh, Khezri Khadijeh. Kojic acid applications in cosmetic and pharmaceutical preparations. Biomedicine and Pharmacotherapy. 2019; Volume 110, 582-593. doi.org/10.1016/j.biopha.2018.12.006

12. Tokiwa, Y.,Kitagawa, M., Raku, T., Yanagitani, S., \& Yoshino, K. Enzymatic synthesis of arbutin undecylenic acid ester and its inhibitory effect on melanin synthesis. Bioorganic and Medical Chemistry Letter. 2007; 17, 3105-3108. DOI: 10.1016/j.bmcl.2007.03.039

13. Zbikowska, B., Franiczek, R., Sowa, A., Połukord, G., Zanowska, B., Sroka, Z. Antimicrobial and Antiradical Activity of Extracts Obtained from Leaves of Five Species of the Genus Bergenia:Identification of Antimicrobial Compounds. Microbial Drug Resistance. 2017; 23 (6): 771 - 780. doi.org/10.1089/mdr.2016.0251 